IUPAC welcomes the Tunisian Chemical Society as one of the latest National Adhering Organization to have joined the Union.

\section{The Tunisian Chemical Society: A Necessity for a Developing Country}

\section{by Mohamed Jemal}

\section{D}

unisia is an Arabic country of about 10 million situated on the south side of the Mediterranean basin. Because of its geographical position, the country has been occupied by various civilizations. For several centuries, Carthage City was the cradle of one of the earliest civilizations in the world. The founding of Carthage by the Phoenicians dates to the 814 s BC.

Tunisia's independence from French colonization occurred in 1956. Since then, education has become the most important part of the state budget. In the first decades after independence, many primary schools were built all over the country, even in the most remote villages. This was followed by the creation of many secondary schools. In 1958, the first Science University was formed, which offered the "Maitrise" and featured a French teaching staff. Thanks to the long-term view of the political leaders at that time, most of the graduate students were sent to France to prepare their theses. Some remained in France, but the majority came back to teach at the young university.

Today, Tunisia boasts 13 universities with about 300000 students-among them a large proportion of scientists - who are taught by Tunisian professors. This rapid and continuous expansion of popular education has improved literacy and produced well-informed citizens, but as with every massive educational policy, it suffers from some drawbacks.

\section{The Case of Chemistry}

Chemistry activity in Tunisia is focused mainly on the extraction and transformation of phosphates, leather treatment, olive oil production and analysis, steel manufacturing, petroleum refining, and food and detergent production.

The Société Chimique de Tunisie (SCT) was launched in 1978 through the initiative of a few young chemists returning from France after stays of four to seven years. Its aim is to promote chemistry in the country through the organization of chemistry meetings, participate in the science curricula commissions launched by the Education Ministry, encourage university-industry connections, and to make citizens aware of the importance of chemistry in everyday life.

The first national meeting organized by SCT was held in November 1979; from that date on, Journées Nationales de Chimie (JNC), national chemistry conferences, have been organized every two years. These meetings attract a large number of young chemists, most of whom could not afford to travel abroad to a chemistry conference.

The SCT used to organize two thematic meetings: the Journées de Chimie Organique (JCO) and the Journées de Chimie du Solide (JCS). The last JCO was combined with the 6th Mediterranean Colloquium on Heterocyclic Chemistry (TRAMECH 6), which took place in Hammamet in November 2009. The last JCS was held in Zarzis (450 km south of Tunis) in December 2009. Two conferences are scheduled for 2010. From 14-16 May 2010, the 41st Journées de Calorimétrie et d'Analyse Thermique will be held in partnership with the Applied Thermodynamics Laboratory, Tunis, under the sponsorship of the Association Française de Calorimétrie et d'Analyse Thermique. From 19-22 December 2010, the 16th JNC will be held, which is expected to have more than 400 participants. As with the previous JNC, the SCT Bureau (12 members) will 
concurrently hold a General Assembly for discussing business matters of the SCT.

SCT meetings feature national and European lecturers on special topics and offer young chemists the opportunity to discuss their results in oral and poster sessions. The SCT also organizes workshops in partnership with the Education Ministry on teaching chemistry in secondary schools and at universities, and with industry on such topics as chromatography, pollution, and energy efficiency. It also participates in activities such as the Science Festivities organized by Tunis El Manar University and takes part in the commission launched by the Higher Education and Research Ministry to prepare for the International Year of Chemistry.
SCT publishes the Journal de la Société Chimique de Tunisie, a twice-a-year, peer-reviewed journal indexed by CAS. It is a member of the Arab Union Chemists and was among the founders of the Federation of African Societies of Chemistry.

SCT adhered to IUPAC in 1990 as an ANAO member and just recently became an NAO member. This new status offers SCT new opportunities at the international level.

Professor Mohamed Jemal <jemal@planet.tn> is president of the Tunisian Chemical Society and contributed to its creation in 1978.

Iii- www.sctunisie.org

\section{IUPAC Around the World (as of March 2010)}

National Adhering Organizations (56)

Associated National Adhering Organizations (3)
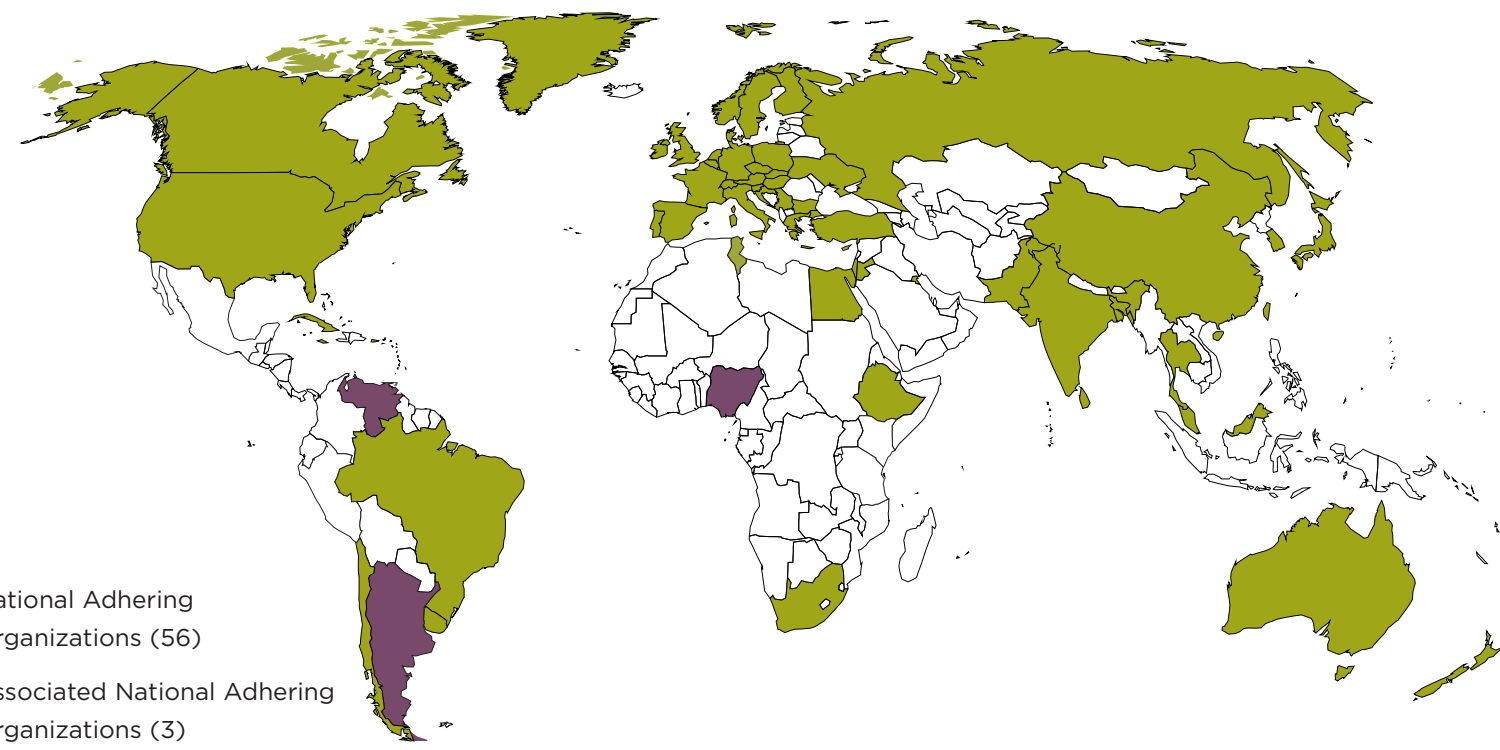

As of 3 March 2010, IUPAC counts 56 full members or National Adhering Organizations (NAOs), and 3 Associated National Adhering Organizations (ANAOs). The most recent adhering members are Cyprus (3 March 2010), Tunisia (4 February 2010), and Luxembourg, Malaysia, Sri Lanka, and Thailand (1 January 2010).

The Membership Relations Committee, currently chaired by Past President Jung-II Jin, appreciates your feedback. Inquiries should be directed to IUPAC Executive Director Terry Renner at <secretariat@iupac.org>.

An informal review of members' benefits, duties, and functions is available online at http://media.iupac.org/general/hints.html. 